\title{
CRYPTOCURRENCY AND THE NIGERIAN ECONOMY
}

\author{
Siyanbola Trimisiu Tunji ${ }^{1}$, Audu Solomon Ibrahim², \\ Adediran Ademola Rashid ${ }^{2}$ and Agbaje AbdulGaniy ${ }^{3}$ \\ ${ }^{1}$ Department of Accounting, Babcock University, Ilishan Remo, Ogun State, Nigeria \\ ${ }^{2}$ Department of Accounting, Caleb University, Imota, Lagos State, Nigeria \\ ${ }^{3}$ Department of Accounting, Fountain University, Osogbo, Osun State, Nigeria
}

Cite this article:

Siyanbola T.T., Audu S.I., Adediran A.R., Agbaje A. (2021), Cryptocurrency and the Nigerian Economy. African Journal of Accounting and Financial Research 4(3), 180-193. DOI: 10.52589/AJAFRTBBBMBOT.

\section{Manuscript History}

Received: 18 Nov 2021

Accepted: 10 Dec 2021

Published: 20 Dec 2021

Copyright $\left({ }_{0} 2020\right.$ The Author(s). This is an Open Access article distributed under the terms of Creative Commons AttributionNonCommercial-NoDerivatives 4.0 International (CC BY-NC-ND 4.0 ), which permits anyone to share, use, reproduce and redistribute in any medium, provided the original author and source are credited.
ABSTRACT: The development of cryptocurrency as a means of exchange without legal backing and invisibility of the identity of operators has posed peculiar challenges such as illicit financial flow and terrorism amongst others, to the country. This study, therefore, sought to examine the effect of cryptocurrency on the Nigerian economy. The study was hinged on social exchange theory. Secondary data were obtained from the CBN statistical bulletin and Global Financial Integrity Report for a period of six years from 2013 to 2018. The data were analyzed using a simple regression model. The result shows that $R$ is $5.8 \%$ which means that there is a low positive relationship between cryptocurrency and the level of economic development in Nigeria. It further shows an adjusted $R$ square of -24.6 which depicts that cryptocurrency has a low inverse effect on the level of economic development in Nigeria. In conclusion, the computed p-value of 0.913 which is higher than the set p-value of 0.05 shows that cryptocurrency does not have a significant effect on the level of economic development in Nigeria. Hence, it is recommended that, in order to sustain economic development from the activities of cryptocurrency in Nigeria, the Central Bank of Nigeria needs to ensure that laws and mechanisms are put in place to adequately capture the activities of cryptocurrency in the country.

KEYWORDS: Cryptocurrency, Economic Development, Illicit Finance, Tax Revenue, Terrorism 


\section{INTRODUCTION}

The Nigerian economy in the current decade has been marred with terrorist activities, illicit financial flow and consequently, a low level of tax to GDP ratio and economic development. Terrorist activities are being carried out by the various groups which have been marked as terrorist groups. For instance, the Boko Haram group has been operating in Nigeria over the last decade which first began as an Islamic ideology group, but over time has carried out violent activities on mosques, churches and other public places which seem like a calculated attempt to destabilize the Nigerian government (Adesoji, 2010; Okafor, 2011). In addition to the Boko Haram group which has been linked to Al Qaeda (Imhonopi \& Urim, 2016), is the herdsmen group from the North that has maimed life and property in the process of ranching their cattle.

Illicit financial flow is evident in Nigeria with monies recovered from loots such as the Abacha loot amongst many other alleged and actually recovered shown by the media. A review of the report shown by the Global Financial Integrity group shows an increased level of illicit financial flow estimate for Nigeria which shows a deteriorating position. Apart from the proceeds of corrupt practices, the activities of multinational firms in Nigeria have been linked with capital flight from Nigeria (host) into the home country of the parent organization (Paul, Kalu, Joseph \& Hyacinth, 2015).

Nigeria's tax revenue to GDP has been shown to be low compared to its contemporary African countries (Audu, 2020; Lethbridge, 2016). Tax revenue is very critical to the sustenance of any economy as it is used to redistribute income and enable the provision of public goods to the teeming populace by the government (Okolie \& Ochei, 2014). Statistics from the Organization for Economic Co-operation and Development (OECD) as pointed out by Audu (2020) revealed that using 2010 as a base year, Nigeria fell short of the average tax to GDP ratio of some top African countries by $7.6 \%$ which is huge and calls for concern for the Nigerian economy which is blessed with abundant natural resources and human capital.

Summarily the Nigerian economy has been reported to have been in recession briefly by the Nigerian Bureau of Statistics after showing a negative GDP for the second and third quarter of the year 2020. This, however, has been shown to be a result of the lockdown of economies put in place to curb the spread of COVID19 (Babatope \& Audu, 2020). This shows how fragile the state of the Nigerian economy is.

Cryptocurrency on the other hand is first traced to 2009 when Bitcoin was created (Egebelogu, Oriakhi, Ojo \& Agu, 2019) and has increased in popularity ever since then. It is a blockchain technology that has the features to be accounted for and can be exchanged in place of another item of value. However, it has been rejected by various governments of sovereign states across the globe (Hughes \& Middlebrook, 2015). One of the reasons put forward toward the rejection of cryptocurrency is due to the non-identification of its users and the high volatility of its value. Various qualitative studies have been carried out on cryptocurrency in an attempt to explain what it is and its impact on the economies of the world (Barone, 2018; Egbelogu, Oriakhi, Ojo \& Agu, 2019; Khrisnan, 2020). A few of the studies on cryptocurrency, however, used quantitative research design but employed the field survey research design (Mazikana, 2018; Salawu \& Moloi, 2018). This creates a methodological gap in which this study attempts to fill by examining the effect of cryptocurrency on the Nigerian economy using the quantitative research design based on macro-economic figures for Nigeria and not based on perceptions of respondents like extant similar studies. 
The remaining part of this study will show the review on the main concepts of this study, a brief review of the theory which is used as the theoretical framework for this study, the methodology of the study and the analysis of data along with the discussion of findings. Finally, the study shows the conclusion inferred based on the result and policy recommendations are given.

\section{CONCEPTUAL REVIEW}

\section{Cryptocurrency}

Cryptocurrency is explained as a digital token that utilizes cryptography which enables the exchange of its value for other items. Dourado and Brito (2014) explained that it can be used at market rates or in the place of legal tenders. They trace the origin of cryptocurrency to the year 2009 where Bitcoin which is a type of cryptocurrency was first showcased. It employed a ledger system referred to as blockchain technology to ensure that cryptocurrency which in this case is Bitcoin is not spent more than once by a user. Bitcoin is not under the control of any Central Bank. However, it possesses two levels of a governance system which are the algorithm and open source governance. In addition, miners who are involved in the process of developing cryptocurrency also ensure the sanctity of the process. European Central Bank in 2012 identified associated risks linked with cryptocurrency ranging from value instability, instability of the payment system, non-existence of laws to back it up and susceptibility of the system to cyber-attack. Examples of cryptocurrency are Bitcoin, Ethereum, Litecoin, Zcash amongst others.

\section{Economic Development}

Economic development is described as a sustained level of economic growth (Feldman, Hadjimichael, Lanahan \& Kemeny, 2016). They represent its measure as

\section{Current year GDP - Previous year GDP}

\section{Previous year GDP}

Joseph and Omodero (2019) confirmed that it is possible for a country to experience economic growth and not experience economic development. Economic growth is usually measured by the gross domestic product GDP which is computed by considering the sum of personal consumption, business investment and government spending. This represents the level of economic activity within the economy.

\section{Illicit Financial Flow}

Joseph and Omodero (2019) explained illicit financial flow to be illegally gotten wealth that is transferred or utilized contrary to the existing rules and regulations that exist in a country. They further posited that these funds are gotten through corrupt practices, operation of an illegal business; sometimes multinational corporations are culpable of moving funds from their subsidiaries to the parent company. Global Financial Integrity group has shown three main areas in which illicit financial flow is made which are: (i) through proceeds of corruption, (ii) international criminal activities and (iii) illegal commercial flight. While avenues through which funds are illegally moved include but are not limited to tax evasion schemes carried out 
by multinational companies, transfer pricing schemes, illegal mining of natural resources, and misappropriation of public funds. World Banks (2015) affirmed that all these illicit means enhance the continual poverty level and reduce taxable income that is required to fund infrastructural development activities and poverty alleviation schemes.

\section{Terrorism}

Trosper (2009) explained terrorism to be the illegal utilization of violence against individuals (i.e. both natural and artificial) or government in order to force them into an ideology. Imhonopi and Urim (2016) adduced terrorism to the use of force that does not conform to criminal laws and which causes bodily harm to individuals and destruction of public properties. Khan (2003) identified about five factors that give rise to terrorist activities as ethnicity, high level of poverty, poor quality of governance, debasement of people and low literacy level.

\section{Tax Revenue}

Somorin (2019) confirmed that tax is a compulsory levy backed up by law. Therefore, the aggregate sum of taxes collected sums up to what is called tax revenue which is the main revenue of government (Okoli \& Ochei, 2014). It is from tax revenue that governments have the resources to provide public goods without incurring debt (Onodje, 2009). Omolehinwa and Naiyeju (2015) explained tax revenue to be a fiscal tool that can be used by the government to tune the economic activities of a country. Hence, tax revenue is an important instrument in any country.

\section{THEORETICAL REVIEW}

The social exchange theory provides the theoretical framework for this study. It was established by George Homans an American sociologist in the year 1961 who posited that relationships are established based on the exchange of values which could be physical or not physical. However, it was critiqued by Miller (2005) who pointed out that the theory presupposes that human interaction is basically due to expected gain from the other party. The theory was further critiqued as having the main objective of a relationship hinged at an intimacy which is not necessarily the main goal of every relationship. In addition, the theory assumes relationships to be in a simple and monotype form whereby in reality relationships exist in various forms. However, Lambe, Wittmann and Spekman (2001) have justified the existence of the theory based on business relationships where relationships are built and sustained based on mutual benefit of the parties involved. They posited that on average, human beings are selfish, which is in line with the ideology of egoism and which drives the capitalist economy. Hence, relationships are maintained due to the exchange of values.

In this regard, this theory is considered suitable for this study as it establishes that cryptocurrency will be held as a medium of exchange only that its value is seen to benefit the holders of it. 


\section{REVIEW OF EXTANT LITERATURE}

Chiu and Koeppl (2017) carried out a study in the United States where they assessed the ability of bitcoin to facilitate bilateral trade using a quantitative research method. They pointed out that cryptocurrency can outperform the traditional model of retail payment when scaling limitation is taken care of.

Similarly, Salawu and Moloi (2018) conducted a study in Nigeria where they assessed the perception of professional accountants on the regulation of cryptocurrency. The survey method was used with a total population of 1,300 chartered accountants but a sample of 250 chartered accountants was conveniently used across various fields. Their study revealed that chartered accountants are ready to trade in cryptocurrency, provided the government properly legislates on its use.

Likewise, Mazikana (2018) examined, the ability of bitcoin to solve the credit crunch in Zimbabwe using the survey research method. Respondents were selected from banks in Zimbabwe. The study revealed that cryptocurrency has potentials but comes with a lot of challenges that need to be addressed for the potentials to be optimized.

Barone (2018) carried out a qualitative research method study by reviewing literature in order to assess cryptocurrency on terrorism. It was discovered that there is a need for the regulation of cryptocurrency in order to curb terrorist finance activities.

Knezevic (2018) carried out a similar study in Serbia with the objective of assessing the effect of blockchain technology on the financial sector. The study employed a qualitative research method by reviewing relevant extant literature. It was pointed out that blockchain technology has a significant effect on the financial sector and has the potential to influence other sectors in the economy.

Adeleke, Zubairu, Abubakar, Maitala, Mustapha and Ediuku (2019) conducted a study in Nigeria by reviewing existing literature on the theme using a qualitative research method. They discovered that there is a paucity of literature on the theme in Africa and that most existing literature employed the survey technique.

Similarly, Egbelogu, Oriakhi, Ojo and Agu (2019) also carried out a study in Nigeria where they examined cryptocurrency on the economy by reviewing relevant literature. They discovered that cryptocurrency has its benefit and demerits if not properly regulated.

Dion-Schwarz, Manheim and Johnstton (2019) assessed the effect of cryptocurrency on counterterrorism finance using the qualitative research method. They found out that there is low regulation on cryptocurrency making it a preferred choice to finance terrorist activities.

Kfir (2020) conducted a study in Australia with the objective of examining the challenges posed by cryptocurrency on national security in relation to terrorism. It was discovered that no international regulatory framework to control cryptocurrency transactions.

Khrisnan (2020) evaluated the effect of blockchain technology on social resistance and terrorism using a qualitative research method where relevant existing literature was reviewed. It was pointed out from the finding of the study that there is a need for regulation of bitcoin activities. 
Agu (2020) evaluated the effect of cryptocurrency on Africa's economy adopting a qualitative research method. It was revealed that despite the fact that some governments in African countries have banned the use of cryptocurrency, it is used in many African countries for legitimate economic activities.

\section{METHODOLOGY}

The quantitative research method is adopted in this study and the ex-post facto research design was used as data were gotten from secondary sources. Secondary data on the variables (cryptocurrency, economic development, illicit finance, terrorism and tax revenue) for 2013 2018 were obtained from a credible online source (stata.com), CBN statistical bulletin and from Global Financial Integrity (GFI) report on illicit financial flow. The simple linear regression was used to assess the effect of the independent variable on the dependent variables while the hypotheses were tested at a $5 \%$ level of significance using the analysis of variance (ANOVA). The linear regression model is represented below:

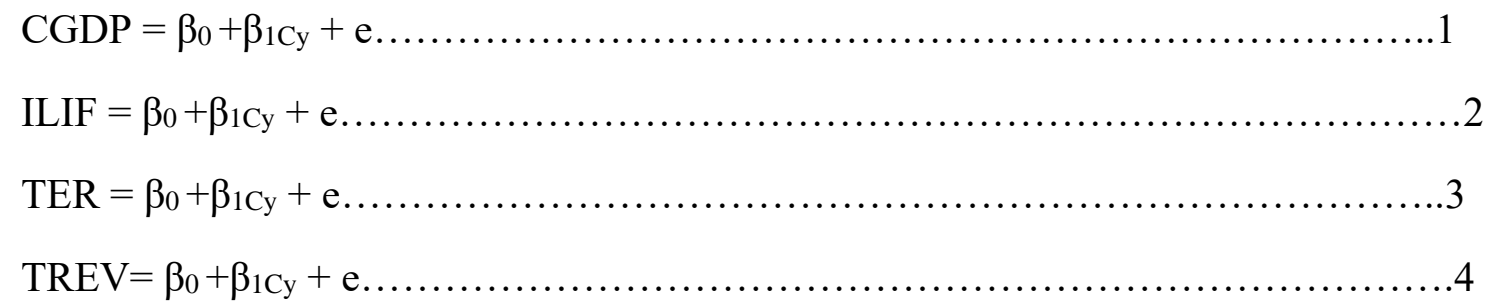

Where

CGDP $=$ Change in Gross Domestic Product (Dependent Variable)

ILIF = Illicit Finance (Dependent Variable)

TER $=$ Terrorism

TREV=Tax Revenue

$\beta_{0}=$ Intercept where independent variable is zero

$\beta_{1 C y}=$ Value of Cryptocurrency transactions (Independent Variable)

$\mathrm{e}=$ error term 


\section{DATA ANALYSIS AND DISCUSSION OF FINDINGS}

\section{Test of Hypotheses}

\section{Hypothesis One}

\section{$\mathrm{H}_{0}$ : There is no significant effect of cryptocurrency on the level of economic development in Nigeria.}

Table 1. Model Summary

\begin{tabular}{|l|r|r|r|c|}
\hline $\begin{array}{l}\text { Mode } \\
1\end{array}$ & \multicolumn{1}{|c|}{$\mathrm{R}$} & $\mathrm{R}$ Square & $\begin{array}{c}\text { Adjusted R } \\
\text { Square }\end{array}$ & $\begin{array}{c}\text { Std. Error of } \\
\text { the Estimate }\end{array}$ \\
\hline 1 & $.058^{\mathrm{a}}$ & .003 & -.246 & 13941.80000 \\
\hline
\end{tabular}

a. Predictors: (Constant), Cryptocurrency

Table 1 reveals that there is a low positive relationship between cryptocurrency and the level of economic development in Nigeria. This is represented by an $\mathrm{R}$ of $5.8 \%$, it also shows that there is a low inverse relationship between the level of cryptocurrency and economic development in Nigeria which is represented by the adjusted R square of $-24.6 \%$. This means that the higher the level of cryptocurrency transactions, the lower the level of economic development in Nigeria.

Table 2. ANOVA ${ }^{\mathrm{a}}$

\begin{tabular}{|c|c|c|c|c|c|}
\hline Model & Sum of Squares & $\overline{\mathrm{Df}}$ & Mean Square & $\bar{F}$ & Sig. \\
\hline Regression & 2605501.963 & 1 & 2605501.963 & .013 & $.913^{b}$ \\
\hline Residual & 777495148.853 & 4 & 194373787.213 & & \\
\hline Total & 780100650.815 & 5 & & & \\
\hline
\end{tabular}
a. Dependent Variable: Economic Growth
b. Predictors: (Constant), Cryptocurrency

Table 2 shows that the computed $p$-value is 0.913 which is higher than the set p-value of 0.05 hence, the null hypothesis states that 'there is no significant effect of cryptocurrency on the level of economic development in Nigeria' is retained.

Table 3. Coefficients ${ }^{\mathrm{a}}$

\begin{tabular}{|rl|r|r|r|r|r|}
\hline \multirow{2}{*}{ Model } & \multicolumn{2}{|c|}{$\begin{array}{c}\text { Unstandardized } \\
\text { Coefficients }\end{array}$} & \multicolumn{2}{c|}{$\begin{array}{c}\text { Standardized } \\
\text { Coefficients }\end{array}$} & \multirow{2}{*}{ Sig. } \\
\cline { 2 - 5 } & \multicolumn{1}{|c|}{ B } & Std. Error & \multicolumn{1}{c|}{ Beta } & & \\
\cline { 2 - 6 } 1 & (Constant) & 14780.963 & 6841.598 & & 2.160 & .097 \\
& Cryptocurrency & $-1.189 \mathrm{E}-010$ & .000 & -.058 & -.116 & .913 \\
\hline
\end{tabular}

a. Dependent Variable: Economic Growth 
Table 3 reveals the value of the integers used in the regression model employed to test hypothesis one. It shows that the integer for the independent variable is negative, further confirming the inverse effect of cryptocurrency on the level of economic development in Nigeria.

\section{Hypothesis Two}

$\mathrm{H}_{0}$ : There is no significant effect of cryptocurrency on the level of illicit financial flow in Nigeria.

Table 4. Model Summary

\begin{tabular}{|l|r|r|r|c|}
\hline $\begin{array}{l}\text { Mode } \\
1\end{array}$ & \multicolumn{1}{|c|}{$\mathrm{R}$} & $\mathrm{R}$ Square & $\begin{array}{c}\text { Adjusted R } \\
\text { Square }\end{array}$ & $\begin{array}{c}\text { Std. Error of the } \\
\text { Estimate }\end{array}$ \\
\hline 1 & $.685^{\mathrm{a}}$ & .469 & .336 & 2640993.08289 \\
\hline
\end{tabular}

a. Predictors: (Constant), Cryptocurrency

Table 4 shows that there is a moderate relationship between cryptocurrency and the level of illicit financial flow in Nigeria. This is represented by $68.5 \%$. The result further shows that there is a low positive effect of cryptocurrency on the level of illicit financial flow in Nigeria which is represented by $33.6 \%$. This shows that the higher the level of cryptocurrency activities, the higher the level of finances routed through illicit financial flow in Nigeria.

Table 5. ANOVA ${ }^{\mathrm{a}}$

\begin{tabular}{|c|c|c|c|c|c|c|}
\hline \multicolumn{2}{|c|}{ Model } & Sum of Squares & $\mathrm{df}$ & Mean Square & $\mathrm{F}$ & Sig. \\
\hline \multirow{3}{*}{1} & Regression & 24600432034985.520 & 1 & 24600432034985.520 & 3.527 & $.134^{\mathrm{b}}$ \\
\hline & Residual & 27899377855547.380 & 4 & 6974844463886.845 & & \\
\hline & Total & 52499809890532.900 & 5 & & & \\
\hline
\end{tabular}
a. Dependent Variable: Illicit Finance
b. Predictors: (Constant), Cryptocurrency

Table 5 reveals that the computed p-value of 0.134 is higher than the set $p$-value of 0.05 , this, therefore, means that the null hypothesis which states that 'there is no significant effect of cryptocurrency on the level of illicit financial flow in Nigeria' is retained.

Table 6. Coefficients ${ }^{\mathrm{a}}$

\begin{tabular}{|rl|r|r|r|r|r|}
\hline \multicolumn{2}{|l|}{ Model } & \multicolumn{2}{|c|}{ Unstandardized Coefficients } & $\begin{array}{c}\text { Standardized } \\
\text { Coefficients }\end{array}$ & $\mathrm{T}$ & Sig. \\
\cline { 2 - 7 } & \multicolumn{1}{|c|}{$\mathrm{B}$} & \multicolumn{1}{c|}{ Std. Error } & \multicolumn{1}{c|}{ Beta } & & \\
\hline \multirow{2}{*}{1} & (Constant) & 5111249.688 & 1296002.910 & & 3.944 & .017 \\
& Cryptocurrency & $3.652 \mathrm{E}-007$ & .000 & .685 & 1.878 & .134 \\
\hline
\end{tabular}

a. Dependent Variable: Illicit Finance 
Table 6 shows the value of the integers that used in testing hypothesis two. It shows that the independent variable has a positive integer which further confirms the nature of the effect of the independent variable on the dependent variable.

\section{Hypothesis Three}

\section{$\mathrm{H}_{0}$ : There is no significant effect of cryptocurrency on the level of terrorism in Nigeria.}

\section{Table 7. Model Summary}

\begin{tabular}{|l|r|r|r|r|}
\hline $\begin{array}{l}\text { Mode } \\
1\end{array}$ & \multicolumn{1}{|c|}{$\mathrm{R}$} & $\mathrm{R}$ Square & $\begin{array}{c}\text { Adjusted R } \\
\text { Square }\end{array}$ & $\begin{array}{c}\text { Std. Error of } \\
\text { the Estimate }\end{array}$ \\
\hline 1 & $.104^{\mathrm{a}}$ & .011 & -.237 & .45084 \\
\hline
\end{tabular}

a. Predictors: (Constant), Cryptocurrency

Table 7 shows that there is a low positive relationship between cryptocurrency and the level of terrorism in Nigeria. This is represented by the $\mathrm{R}$ result of $10.4 \%$. It further reveals that cryptocurrency activities have a low inverse effect on the level of terrorism in Nigeria. This is shown by the adjusted $\mathrm{R}^{2}$ result of $-23.7 \%$. It, therefore, means that an increase in the level of cryptocurrency activities does not necessarily lead to an increase in the level of terrorism in Nigeria.

Table 8. ANOVA ${ }^{\mathrm{a}}$

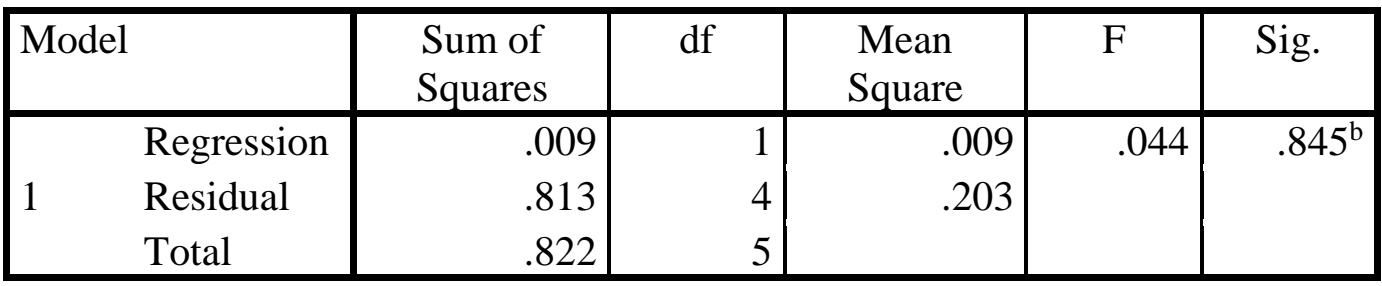

a. Dependent Variable: Terrorism

b. Predictors: (Constant), Cryptocurrency

Table 8 reveals the computed p-value is 0.845 which is higher than the set p-value of 0.05 which is set for this study. Therefore, the alternate hypothesis is rejected and the null hypothesis which states that 'there is no significant effect of cryptocurrency on the level of terrorism in Nigeria' is retained.

Table 9. Coefficients ${ }^{\mathrm{a}}$

\begin{tabular}{|rl|r|r|r|r|r|}
\hline \multirow{2}{*}{ Model } & \multicolumn{2}{|c|}{$\begin{array}{c}\text { Unstandardized } \\
\text { Coefficients }\end{array}$} & \multicolumn{2}{c|}{$\begin{array}{c}\text { Standardized } \\
\text { Coefficients }\end{array}$} & \multirow{2}{*}{ Sig. } & \\
\cline { 2 - 5 } & \multicolumn{1}{|c|}{ B } & Std. Error & \multicolumn{1}{c|}{ Beta } & & \\
\hline \multirow{2}{*}{1} & (Constant) & 8.907 & .221 & & 40.261 & .000 \\
& Cryptocurrency & $-1.069 \mathrm{E}-013$ & .000 & -.104 & -.209 & .845 \\
\hline
\end{tabular}

a. Dependent Variable: Terrorism 
Table 9 discloses information on the integer of the independent variable and the intercept used in the regression model. It shows that the integer value for cryptocurrency is negative while that of the intercept is positive.

\section{Hypothesis Four}

\section{$\mathrm{H}_{0}$ : There is no significant effect of cryptocurrency on the level of tax revenue in Nigeria.}

Table 10. Model Summary

\begin{tabular}{|l|r|r|r|r|}
\hline $\begin{array}{l}\text { Mode } \\
1\end{array}$ & \multicolumn{1}{|c|}{$\mathrm{R}$} & R Square & $\begin{array}{c}\text { Adjusted R } \\
\text { Square }\end{array}$ & $\begin{array}{c}\text { Std. Error of } \\
\text { the Estimate }\end{array}$ \\
\hline 1 & $.125^{\mathrm{a}}$ & .016 & -.230 & 636.42444 \\
\hline
\end{tabular}

a. Predictors: (Constant), Cryptocurrency

Table 10 shows that there is a low positive relationship between cryptocurrency activities in Nigeria and the level of tax revenue generated in Nigeria. This is disclosed by the result of $\mathrm{R}$ which is $12.5 \%$. It further reveals that cryptocurrency has an inverse effect on the level of tax revenue in Nigeria. This result is shown by the adjusted $\mathrm{R}^{2}$ of $-23 \%$. This can be further interpreted as- the higher activities in cryptocurrency, the lower the level of tax revenue generated in Nigeria.

Table 11. ANOVA ${ }^{\mathrm{a}}$

\begin{tabular}{|rl|r|r|r|r|r|}
\hline \multicolumn{2}{|l|}{ Model } & \multicolumn{1}{c|}{$\begin{array}{c}\text { Sum of } \\
\text { Squares }\end{array}$} & df & $\begin{array}{c}\text { Mean } \\
\text { Square }\end{array}$ & F & Sig. \\
\hline \multirow{2}{*}{1} & Regression & 25850.385 & 1 & 25850.385 & .064 & $.813^{\mathrm{b}}$ \\
& Residual & 1620144.296 & 4 & 405036.074 & & \\
\hline & Total & 1645994.681 & 5 & & & \\
\hline
\end{tabular}

a. Dependent Variable: Tax Revenue

b. Predictors: (Constant), Cryptocurrency

Table 11 reveals the computed p-value of 0.813 which is higher than the set $p$-value of the study which is 0.05 . Hence, the alternate hypothesis is rejected and the null hypothesis which states that 'there is no significant effect of cryptocurrency on the level of tax revenue in Nigeria' is retained.

Table 12. Coefficients ${ }^{\mathrm{a}}$

\begin{tabular}{|rl|r|r|r|r|r|}
\hline \multirow{2}{*}{ Model } & \multicolumn{2}{|c|}{$\begin{array}{c}\text { Unstandardized } \\
\text { Coefficients }\end{array}$} & $\begin{array}{c}\text { Standardized } \\
\text { Coefficients }\end{array}$ & \multirow{2}{*}{ Sig. } & \\
\cline { 2 - 5 } & \multicolumn{1}{|c|}{ B } & \multicolumn{1}{c|}{ Std. Error } & \multicolumn{1}{c|}{ Beta } & & \\
\hline \multirow{2}{*}{1} & (Constant) & 4144.353 & 312.310 & & 13.270 & .000 \\
& $\begin{array}{l}\text { Cryptocurren } \\
\text { cy }\end{array}$ & $-1.194 \mathrm{E}-$ & .000 & -.125 & -.253 & .813 \\
\hline
\end{tabular}

a. Dependent Variable: Tax Revenue 
Table 12 shows the values of the intercept and independent variable integers of the regression model. It reveals that the independent variable has a negative integer while the intercept has a positive integer.

\section{DISCUSSION OF FINDINGS}

The results from Tables 1 and 2 shows an adjusted R-square of $-24.6 \%$ while the computed value is 0.916 which shows that cryptocurrency does not have a significant effect on the development of the Nigerian economy. The regression result means that if the cryptocurrency is used in Nigeria, the lower the level of economic development even though it will be at an insignificant level. This is not in tandem with Mazikana (2018) who stated that cryptocurrency has a lot of potential in ensuring that the economy is buoyant but needs proper regulation and guidelines to ensure that this is so. The finding from this study is evidence of this as Nigeria currently doesn't have any regulation on cryptocurrency which might be the reason for the abysmal result.

In addition, results from Tables 4 and 5 show an adjusted $\mathrm{R}$ square of 33.6 and a computed pvalue of 0.134 which shows that cryptocurrency has a positive effect on the illegal financial flow in Nigeria which is insignificant. However, it shows that the more the level of cryptocurrency activity in Nigeria, the higher the level of illicit financial flow in Nigeria. This is in agreement with the position of Barone (2018), who called for its regulation in order to curb the illicit financial flow.

Furthermore, Tables 7 and 8 reveal an adjusted R square of -23.7 and a computed p-value of 0.845 which shows that cryptocurrency has an inverse effect on the level of terrorism in Nigeria which is not significant. This means that the more cryptocurrency activities are engaged in the higher the level of successful terrorism activities carried out in Nigeria. This is also in sync with the work of Barone (2018) who posited that there is an important need for regulation of cryptocurrency so that it will not be used for terrorist financing. Finally, Tables 10 and 11 show an adjusted R-square of $23 \%$ and a computed value of 0.813 . This indicates that cryptocurrency does not have a significant effect on the level of tax revenue in Nigeria. It, however, shows that the higher the level of cryptocurrency activities in Nigeria, the lower the level of tax revenue in Nigeria which shows that taxes might be evaded via cryptocurrency use currently in Nigeria. This is also in agreement with the position of (Egbelogu, Oriakhi, Ojo \& Agu, 2019 \& Kfir, 2020) who also pointed out the need for regulation of cryptocurrency activities in Nigeria. However, the social exchange theory explains why the insignificance between cryptocurrency and the Nigerian economy which can be explained partly due to its high volatility in value. Hence, the level of individuals who subscribe to its operation is insignificant as rightly shown by the findings of this study.

\section{CONCLUSION}

This study was carried out to examine the effect of cryptocurrency on the Nigerian economy. The result of the analysis shows that cryptocurrency has a low inverse effect on the level of economic development of Nigeria and a low positive effect on the level of illicit financial flow in Nigeria. It further reveals that cryptocurrency has a low inverse effect on the level of 
terrorism and tax revenue in Nigeria. In summary, the result can be explained as depicting that cryptocurrency has no significant effect on the Nigerian economy.

\section{RECOMMENDATION}

From the finding of the study, the following recommendations are made:

First of all, the government through the financial industry regulators such as the Central Bank of Nigeria $(\mathrm{CBN})$ need to set up regulations to ensure that cryptocurrency inflow is promoted into the country in order to reverse the negative effect on economic development.

In addition, the Central Bank of Nigeria needs to set up means of identifying owners of cryptocurrency accounts so as to curb the menace of illicit financial flow in Nigeria and to further promote transparency in its activities.

Lastly, the legislative arm of government in conjunction with the Ministry of Finance and the Federal Inland Revenue Service need to promote the establishment of tax laws and mechanisms in order to ensure that taxable transactions in which cryptocurrency is used as a means of settlement are captured into the tax revenue net.

\section{REFERENCES}

Adeleke, I., Zubairu, U. M., Abubakar, B., Maitala, F., Mustapha, Y., \& Ediuku, E. (2019). A systematic review of cryptocurrency scholarship. International Journal of Commerce and Finance, 5(2), 63-75.

Adesoji, A. (2010). The Boko Haram uprising and Islamic revivalism in Nigeria. Africa Spectrum, 45(2), 95-108.

Agu, C. J. (2020). Impact of cryptocurrency on Africa's economy. 1-4.

Audu, S. I. (2020). Pattern of spending and the level of tax revenue in Nigeria. International Journal of Research and Innovation in Social Science, 4(9), 561-567.

Babatope, B. B., \& Audu, S. I. (2020). Accountability and economic growth in Nigeria Pre COVID-19. African Journal of Sustainable Development, 10(3), 61-75.

Barone, D. M. (2018). Jihadists use of cryptocurrencies: undetectable ways to finance terrorism. International Journal of Italian Team for Security, Terroristic Issues \& Managing Emergencies, 8(2), 17-59.

Chiu, J., \& Koeppl, T. V. (2017). The economics of cryptocurrencies- Bitcoin and Beyond. 155. doi:10.2139/ssrn.3048124

Dion-Schwarz, C., Manheim, D., \& Johnston, P. B. (2019). Technical and organizational barriers and future threats. Santa Monica: RAND Corporation.

Dourado, E., \& Brito, J. (2014). Cryptocurrency. The New Palgrave Dictionary of Economics, 1-10.

Ebelogu, C. U., Oriakhi, J. E., Ojo, S. D., \& Agu, E. O. (2019). Cryptocurrency (blockchain) technology as a means of leveraging the Nigerian economy. International Journal of Advances in Scientific Research and Engineering, 5(12), 139-146. doi:10.31695/IJASRE.2019.33657 
Feldman, M., Hadjimichael, T., Lanahan, L., \& Kemeny, T. (2016). The logic of economic development: A definition and model for investment. Government and Policy, 34(1), 521. doi:10.1177/0263774x15614653

Homans, G. (1961). Social behaviour. Its elementary forms. New York: Brace Jovanovich. Hughes, S., \& Middlebrook, S. (2015). Advancing a framework for regulating cryptocurrency payments intermediaries. Yale Journal on Regulation, 32(2), 495.

Imhonopi, D., \& Urim, U. M. (2016). The spectre of terrorism and Nigeria's industrial development. A multi-stakeholder imperative. African Journal of Criminology and Justice Studies, 9(1), 20-40.

Joseph, F. I., \& Omodero, C. O. (2019). Illicit financial flow and the growth of the Nigerian Economy. International Journal of Economics and Financial Modelling, 4(1), 13-24.

Kfir, I. (2020). Cryptocurrencies, national security, crime and terrorism. Comparative Strategy, 39(2), 113-127. doi:10.1080/01495933.2020.1718983

Khan, R. (2003). Can terrorism be beaten by military means? Global Policy Forum.

Knezevic, D. (2018). Impact of the blockchain technology platform in changing the financial sector and other industries. Montenegrin Journal of Economics, 14(1), 109-120.

Krishnan, A. (2020). Blockchain empowers social resistance and terrorism through decentralized autonomous organizations. Journal of Strategic Security, 13(1), 41-58. doi:10.5038/1944-0472.13.1.1743

Lambe, C. J., Wittmann, C. M., \& Spekman, R. E. (2001). Social exchange theory and research on business to business relational exchange. Journal of Business to Business Marketing, 8(3), 1-36. doi:10.1300/j033v08n03_01

Lethbridge, J. (2016, September). Tax justice in Nigeria. Public Services International Research Unit, 2, 2-16.

Mazikana, A. T. (2018). Impact of cryptocurrencies in Zimbabwe: An analysis of Bitcoins. Unpublished PhD Thesis, 1-84.

Okafor, E. E. (2011). Dynamics of Niger Delta struggle and the state responses: The state of terrorism and terrorism of the state. Journal of Sustainable Development in Africa, 13(2), 1520-5509.

Okolie, O. R., \& Ochei, C. M. (2014, December). An examination of the Nigerian fiscal federalism and its impact on revenue generation for economic development.

International Journal of Economics, Commerce and Management, 2(12), 1-20.

Omolehinwa, E. O., \& Naiyeju, J. K. (2015). Government accounting in Nigeria: An IPSAS approach (1st ed.). Lagos: Punmark Nigeria Limited.

Onodje, M. A. (2009). An insight into the behaviour of Nigeria's private consumer spending. African Journal of Business Management, 3(9), 383-389. doi:10.5897/AJBM09.065

Paul, C., Kalu, E., Joseph, C., \& Hyacinth, O. (2015). The impact of capital flight on economic development: Nigeria in focus. British Journal of Economics, Management and Trade, 10(3), 1-13.

Salawu, M. K., \& Moloi, T. (2018). Benefits of legislating cryptocurrencies: Perception of Nigerian professional accountants. Academy of Accounting and Financial Studies Journal, 22(6), 1-17.

Somorin, O. A. (2019). Taxpayer: Voices, Disconnect and Tax Compliance. Caleb University 4th Inaugural Lecture. Lagos: Caleb University.

Trosper, T. B. (2009). West Africa's war on terrorism: A new guide to actors, authors, concepts, databases, theories, and literature. New Jersey: Transaction Books. 
APPENDIX

\begin{tabular}{|c|c|c|c|c|c|}
\hline Year & $\begin{array}{c}\text { Cryptocurrency } \\
\text { Volume (a) }\end{array}$ & GDP (b) & $\begin{array}{c}\text { Illicit } \\
\text { Finance (c) }\end{array}$ & Terrorism (a) & Tax (b) \\
\hline & ${ }^{\prime} 000$ & N Billion & N Billion & $\%$ & N Billion \\
\hline 2013 & 24,036 & 8378.62 & $\begin{array}{c}4213569.6 \\
8\end{array}$ & 8.2 & $4,805.60$ \\
\hline 2014 & 188,879 & 38951.1 & 2414367 & 9.21 & $4,714.60$ \\
\hline 2015 & $1,213,840$ & 5101.34 & 4277174.5 & 9.31 & $3,741.80$ \\
\hline 2016 & $347,357,267$ & 7344.53 & 8350060.5 & 9.01 & $3,307.50$ \\
\hline 2017 & $7,185,577,493$ & 12222.1 & 10464174 & 8.66 & $4,027.94$ \\
\hline 2018 & $14,655,114,830$ & 14050.9 & 9051480 & 8.9 & $4,006.00$ \\
\hline
\end{tabular}

\section{Source}
a. statisca.com
b. CBN Statistical Bulletin, 2018
c. Global Financial Integrity Report, 2018 